\title{
Covid-19: how doctors and healthcare systems are tackling coronavirus worldwide
} As coronavirus continues to spread, doctors and healthcare systems are facing a multitude of
challenges at all stages of the pandemic

\author{
Janice Hopkins Tanne ${ }^{1}$, Erika Hayasaki ${ }^{2}$, Mark Zastrow ${ }^{3}$, Priyanka Pulla ${ }^{4}$, Paul Smith ${ }^{5}$, Aser Garcia \\ Rada $^{6}$
}

${ }^{1}$ New York; ${ }^{2}$ Boston; ${ }^{3}$ Seoul; ${ }^{4}$ Bangalore; ${ }^{5}$ Sydney; ${ }^{6}$ Madrid

\section{United States}

The United States declared a national emergency on 13 March as covid-19 spread to 49 of the country's 50 states.

President Donald Trump announced \$50bn (£42.1bn; €45.6bn) to help combat the virus, as well as powers to waive laws and restrictions to make care more available, such as through telehealth and allowing doctors to practise in states they are not licensed in.

The president-who has tested negative for covid-19 after contact with an infected Brazilian official—said that many more test kits would soon be available, as would a website to guide people as to signs of infection and whether they should seek testing. The vice president, Mike Pence, who is in charge of response to the outbreak, said that the focus was on the partnership between the government, private companies, and commercial and public laboratories to make widespread testing available. About 2000 laboratories would soon be able to process the tests, he said.

The US government had faced mounting criticism over its response and admitted to failing to provide enough test kits. In the 13 March press conference Trump said that the Food and Drug Administration had approved a new test from the drug manufacturer Roche and that half a million of the kits would be available by 22 March, five million within a month. Deborah Birx, the White House response coordinator for covid-19, said that the tests would provide answers within 24 to 36 hours.

The president also said that the Centers for Disease Control and Prevention (CDC) would open a website (www.coronavirus. gov $)^{1}$ to help people decide whether they should seek testing. Leaders of commercial testing laboratories, drug store chains, and mass market retailers said that they would soon open drive-through testing facilities in their parking lots, including least one site already open in the New York City suburb of New Rochelle, handling around 250 people a day.

The American Medical Association, which represents about half of US doctors, called the emergency declaration "necessary to help ensure that America's health system has sufficient resources." Meanwhile, some doctors complained that they did not have test kits and were short of protective equipment. Other physicians said that access to Medicaid, insurance for poor patients, should be improved and sped up.

At a 15 March press conference Anthony Fauci, head of the National Institute of Allergy and Infectious Diseases, told the public, "If it looks like you're over-reacting, you're probably doing the right thing." Staying home if ill, social distancing, and frequent handwashing have been recommended. He said that public health officials were trying to prevent new infections from entering the US and mitigating spread in the country. He warned that the situation would get worse before it got better.

Criticisms of the government's response continue, as several states have complained about a lack of coordinated national response and confused messaging from the White House that have had huge impacts on the ground. People rushing to return to the US from Europe-from which the government has instigated a travel ban-reported waits of four to eight hours to go through required airport examinations at the 13 airports accepting these flights, sparking alarm about the infection risk from crowds.

\section{Japan}

Cases in Japan have slowed in the weeks since the Diamond Princess cruise ship—responsible for nearly 700 cases-was cleared, and the government enacted emergency measures including the shutdown of all schools for the month of March and a public lockdown in the northern prefecture of Hokkaido. 
But doctors worry whether the level of testing is adequate in a country hit early in the epidemic and that the true numbers of infections is unknown.

Masahiro Kami, executive director of Japan's Medical Governance Research Institute, a non-profit group, is concerned that only people showing the most severe symptoms are being tested. Most people who become infected will "have no symptoms or be mildly ill," said Kami. "In Japanese practice, these people do not undergo PCR [polymerase chain reaction] tests" for the virus.

Japan currently has capacity to conduct about 6000 coronavirus tests a day, and its health officials hope that this will rise to 7000 a day by the end of March, said Sahara Yasuyuki, the country's senior assistant minister for global health, at a 10 March news conference. Yet the number of actual tests being administered is currently around half of that daily capacity.

At the time of writing, Japan reports 889 confirmed cases and 29 deaths (excluding the Diamond Princess). It's not yet an "explosive outbreak," said Yasuyuki, but it's also "not possible to relax the level of monitoring and caution." Yasuyuki said that the difference between available tests and administered tests might be attributed to a low number of cases in which doctors actually deem it necessary to conduct the tests.

Kentaro Iwata, a professor in the Division of Infectious Disease Therapeutics at Kobe University Graduate School of Medicine, told The BMJ that it was still "difficult to distinguish who is a candidate for coronavirus infections, as symptoms are so non-specific." Iwata believes that more testing is not necessarily the answer. "For mild cases, staying at home without testing is a better strategy," he said.

Japan has the largest proportion of elderly people in the world-over $26 \%$ of its citizens. ${ }^{2}$ Kami worries about the virus hitting this already vulnerable population. "Isolating them in a hospital can be a great stress, and some people die," he said. "The only way to deal with these problems is to keep them from getting infected." But to do this, he explained, the Japanese government must increase testing, even with people who don't seem severely infected, and do everything it can to keep the virus out of facilities that serve the elderly populations. "The Japanese government takes this lightly," he said.

Healthcare officials worry that the worst is still to come and that, if that happens, the system will face grave challenges. Iwata's deepest concern is that many people will die of covid-19 infections and that there will not be "enough hospitals and professionals to deal with them, as we see in Italy."

\section{India}

The world's second most populous country seems to have avoided the worst of the pandemic so far, with 83 people confirmed as infected. ${ }^{3}$ These patients were either travellers from covid-19 affected countries or their close contacts, the Indian health ministry has said. This puts India in the "local transmission" category, according to the World Health Organization's classification system, meaning that there are no cases that cannot be linked to travel related covid-19 patients.

However, public health experts have questioned the government's claim. They say that, because only 52 laboratories around the country are testing for SARS-CoV-2 (the virus strain that causes covid-19) and that this testing is restricted to travel related cases and their contacts, the country could be missing more widespread transmission. Without testing random cases of pneumonia with no travel history it's impossible to be sure that only local transmission is occurring, Giridhar R Babu, an epidemiologist at New Delhi's Public Health Foundation of India, told The BMJ.

If wider "community" transmission occurs, the worry is that India doesn't have the healthcare infrastructure to handle it. "Our system is simply not capable of handling even the bare minimum scenario of $1 \%$ of the population being affected by covid-19," said Babu. The country has only 1.3 hospital beds for every 1000 people, ${ }^{4}$ against a WHO recommendation of 3.5. Intensive care beds and mechanical ventilators, needed for treating severe covid-19 cases, are also in short supply.

One cause for optimism, however, is India's unprecedented measures to contain further transmission: it cancelled all visas to the country and asked states to invoke the Epidemics Diseases Act, a legislation that allows officials to quarantine suspected cases or close down public places. Some states, such as Karnataka, have taken the cue to announce a weeklong shutdown of malls, movie theatres, and schools.

\section{South Korea}

South Korea's overall pace of reported new cases has slowed dramatically from its peak on 29 February, when it recorded 909 new cases, down to 74 on 16 March.

However, clusters continue to break out throughout the nation, including in and around Seoul, a metropolitan area of over 25 million people. In a meeting with regional leaders on 16 March the president, Moon Jae-in, said that the country could not let its guard down or let up on social distancing efforts.

The peak of South Korea's outbreak saw several hundreds of cases a day in Daegu city and its surrounding North Gyeongsang province, and most cases were linked to a regional religious sect called Shincheongji. The surge in cases stretched hospitals: 2300 people were left waiting for admittance at one point in early March, and at least two people died waiting for a hospital room. ${ }^{5}$

Reports of fatigue among healthcare workers were widespread. Sixteen of 100 nurses at Pohang Medical Center resigned from 29 February and 1 March owing to "various personal reasons compounded by overwork," the Yonhap national wire agency reported. ${ }^{6}$ Daegu Medical Center put out a plea for doctor and nurse reinforcements, and 250 physicians responded. ${ }^{7}$

However, regions were never put into strict lockdown. Rather, authorities called for voluntary social distancing and isolation, which the public largely heeded.

The nation's response also included aggressive scaling up of testing (as many as 18000 a day have been conducted) and contact tracing using CCTV and credit card transactions. Under South Korean law regional authorities can also make public all movements of infected patients, which they have been doing through blog posts and text alerts. Though effective, this has drawn the ire of privacy advocates and critics who fear that it may dissuade people from coming forward to be tested.

\section{Spain}

The Spanish cabinet declared a state of emergency on 14 March, placing the entire country in lockdown. Travel and all commercial activities have been shut down, except for food shops and some essential services such as pharmacies.

Spain is the second hardest hit country in Europe, after Italy. At the time of writing 13716 people have been confirmed infected—nearly half from the region of Madrid—with 598 deaths and at least 774 patients in intensive care, and 1081 people have been discharged. The national government has 
assumed sole command throughout Spain's state territories under the leadership of the Ministry of Health and has taken control of all private medical facilities in the country to help shoulder the burden. All public and private spaces can also be enlisted to help provide temporary locations to care for patients.

A 15 March protocol issued by the Ministry of Health reserves laboratory diagnostic tests for admitted patients or those in need for admission with acute respiratory symptoms, as well as essential service personnel, such as healthcare workers, with acute respiratory symptoms. ${ }^{8}$

In Madrid, large hospitals are already facing severe patient overloads. Dozens of health workers have been affected by contagion or quarantine, further exacerbating the situation. The biggest concerns are insufficient personal protective equipment (PPE), such as gloves or masks, and the limited availability of ventilators and intensive care beds because of the volume of critical patients being admitted each day.

Scheduled surgeries and medical appointments that may be delayed have been cancelled. Primary care doctors are attempting to provide consultations by telephone, giving preference to elderly patients and people with multiple pre-existing conditions.

\section{Australia}

The crisis has yet to hit Australia, despite worldwide attention after the quarantining of the US actors Tom Hanks and Rita Wilson, who tested positive for the virus while filming in the country.

Case numbers remain relatively low: 568 confirmed cases at the time of writing, with six deaths. But concern remains that a country currently in summer will be harder hit as winter sets in.

People who have been in contact with diagnosed cases are being told to self-isolate for 14 days and to get tested if they develop symptoms. All people arriving from overseas are also required to self-isolate for 14 days. Since 16 March there has been a ban on all non-urgent gatherings of 500 people or more. ${ }^{9}$

GPs have expressed exasperation at the inconsistent messages coming from the numerous public health authorities. They report fearful patients turning up without warning, ignoring official advice to call first. ${ }^{10}$

Another issue has been the lack of PPE for GPs to safely swab patients who meet the current criteria for testing. ${ }^{10}$ On 13 March Australia's chief medical officer, Brendan Murphy, wrote to doctors to emphasise that the supply of test kits, reagents, and swabs "was deteriorating rapidly," as kits were no longer available in some regions owing to current demand. ${ }^{11}$

But the government is acting. Historically, under Australia's Medicare fee-for-service system, the government has for all intents and purposes funded GP care only when the GP is face to face with the patient. For the next six months, however, there will be funding to provide telehealth consultations and triage to vulnerable groups such as elderly people, those with chronic conditions, pregnant women, and people who are immunocompromised, after a vocal campaign by doctor groups. ${ }^{12}$ This temporary relaxation of the Medicare rules should mean that far more medical care is provided remotely in the coming weeks.

The government has also pledged to roll out 100 dedicated "fever" clinics led by nurses and doctors. The intention is to move patients who need screening away from mainstream health services. As a stop gap measure, some general practices-including a practice run by Mukesh Haikerwal, a former president of the Australian Medical Association-have set up drive-through clinics, where patients are swabbed through the side window of their cars. ${ }^{13}$

\section{China}

The Chinese authorities have trumpeted the success of strict and thorough measures, including a complete lockdown of the epidemic centre of Wuhan and surrounding Hubei province, as well as major cities such as Beijing and Shanghai. Worldwide cases have now surpassed total cases in China, and the Chinese say that their actions helped see the country through the peak of infections and bought time for other countries to prepare.

Health authorities reported just 16 new cases on 15 March, 12 of which were people who had entered China from other countries. Workplaces and shops have begun reopening throughout the country, including in Hubei province. The government also announced that all of the temporary hospitals it had erected had been closed. ${ }^{14}$

China is now extending cooperation to other countries, having sent a plane of nine doctors and nine pallets of medical equipment to help Italy. ${ }^{15}$ The worry now is of re-imported cases from elsewhere in the world. State media reported that Beijing will funnel overseas travellers suspected of having coronavirus to a makeshift hospital built to handle SARS patients in $2003 .{ }^{16}$

\section{France}

France has closed its borders in coordination with other EU countries, as the French government ordered all citizens to stay at home for 15 days. ${ }^{17}$ President Emanuel Macron has called covid-19 "the worst health crisis in a century." 18

Jérôme Salomon, France's director general of health, said that the situation was "deteriorating very fast," with cases doubling every three days. "I want our citizens to realise that there are people who are sick, who are in intensive care, and that [their number] runs into hundreds," reported France $24 .{ }^{17}$ Salomon told $C N N$ that over $50 \%$ of patients in intensive care were under 60 years old. ${ }^{19}$

Meanwhile, there was confusion as Olivier Veran, health minister, tweeted that anti-inflammatory painkillers such as ibuprofen could worsen the effects of the virus despite a lack of publicly available evidence. ${ }^{20}$ However, UK doctors and scientists have since backed the claim. ${ }^{21}$

\section{Germany}

Like France, Germany has shut its borders to neighbouring countries. ${ }^{22}$ Authorities reported over 1000 new cases on 15 March, with total cases topping 10 000. Schools, museums, galleries, theatres, gyms, and nightclubs have been closed, and events with more than 50 attendees are banned.

Meanwhile, there was anger at a report that the US government had attempted to secure "exclusive" access to a covid-19 vaccine. ${ }^{23}$ The Trump administration reportedly offered $\$ 1$ bn to a Tübingen based biopharmaceutical company, CureVac, to secure the vaccine "only for the United States," the Welt am Sonntag newspaper reported. The US denies taking any such action. 


\section{Iran}

In the third worst affected country in the world, concern is rising that the pandemic will overwhelm a healthcare system already buckling from US sanctions.

Iran has around 110000 hospital beds, including 30000 in the capital, Tehran, said a report in Politico. ${ }^{24}$ Authorities have pledged to set up mobile clinics as needed.

Health Ministry figures report that $55 \%$ of fatalities are patients in their 60s and that around $15 \%$ were under 40, said Politico. ${ }^{24}$ As of 15 March there were 724 official deaths and nearly 14 000 cases, but the real number of infections could be much higher, with doubts surrounding the government's transparency despite several politicians becoming infected. The government has released 85000 prisoners as a precautionary measure. ${ }^{25}$

The secrecy has led to misinformation, with a reported 44 deaths from bootleg alcohol poisoning after a false rumour that drinking could cure the disease. ${ }^{26}$

\section{Canada}

Canada has closed its borders to all foreign nationals except for US citizens as the prime minister, Justin Trudeau, whose wife has tested positive for the virus, urged all citizens to stay at home. ${ }^{27}$

As covid-19 infections rapidly rise, Canada's chief medical officer of health, Theresa Tam, warned that the window to "flatten the curve" of growth was narrowing. ${ }^{28}$

Regional governments have enacted varying measures. The Globe and Mail reported that Alberta had closed schools and day cares indefinitely, and Quebec had ordered the closing of all public and private recreational establishments, while Ontario banned jail visits and postponed court trials. ${ }^{29}$

\section{Italy}

See Feature: "On the front lines of coronavirus: the Italian response to covid-19" on bmj.com (https://www.bmj.com/ content/368/bmj.m1065). ${ }^{30}$

Competing interests: The authors have read and understood BMJ policy on declaration of interests and have no relevant interests to declare.

Provenance and peer review: Commissioned; not externally peer reviewed.

Correction: We amended this article on 30 March to correct the spelling of an author's name, Aser Garcia Rada.

1 CDC. Coronavirus disease 2019 (COVID-19): get your mass gatherings or large community events ready for coronavirus disease 2019. 2020.

2 Kubo T. Shrinking and super-aging suburbs in Japanese metropolis. Research Gate. Ap 2017. https://www.researchgate.net/profile/Tomoko_Kubo3/publication/321221881_ Shrinking_and_Super-Aging_Suburbs_in_Japanese_Metropolis/links/ 5b875356a6fdcc5f8b710d7e/Shrinking-and-Super-Aging-Suburbs-in-Japanese-Metropolis pdf.

3 Government of India. Ministry of Health and Welfare. https://www.mohfw.gov.in/.

3 Government of India. Ministry of Health and Welfare. https://www.mohfw.gov.in/.
4 PWC. Future of India: the winning leap. 2014. https://www.pwc.com/sg/en/publications/ assets/future-of-india-the-winning-leap.pdf.
5 How a South Korean city is changing tactics to tamp down its covid-19 surge. NPR 2020. https://www.npr.org/sections/goatsandsoda/2020/03/10/812865169/how-a-south-koreancity-is-changing-tactics-to-tamp-down-its-covid-19-surg

6 Medical staff under pressure amid spiking virus cases in S. Korea. Yonhap 2020 Mar 2 https://en.yna.co.kr/view/AEN20200302002551320.

7 Doctors, health workers volunteer to help mitigate coronavirus crisis in Daegu, $\mathrm{N}$. Gyeongsang. Hankyoreh $2020 \mathrm{Feb} 27$. http://english.hani.co.kr/arti/english_edition/e_ national/930202.html.

8 Ministerio de Sanidad. Procedimiento de actuación frente a casos de infección por el nuevo coronavirus (SARS-CoV-2). Actualizado a 15 de marzo de 2020 [Ministry of Health. Protocol against cases of infection by the new coronavirus (SARS-CoV-2). Updated 15 Mar 2020]. 2020. https://www.mscbs.gob.es/profesionales/saludPublica/ccayes/ alertasActual/nCov-China/documentos/Procedimiento_COVID_19.pdf.

9 Worthington B. Gatherings of more than 500 people to be cancelled amid coronavirus fears. $A B C$ 2020. https://www.abc.net.au/news/2020-03-13/coronavirus-scott-morrisoncoag-premiers-cancelling-events/12053382.

10 Smith P. "Left in the dark": $90 \%$ of GPs denied the equipment to safely test patients for COVID-19. Ausdoc 2020 Mar 6. https://www.ausdoc.com.au/news/left-dark-90-gps-deniedequipment-safely-test-patients-covid19.

11 Murphy B. Chief Medical Officer update on coronavirus testing. RACGP. 2020 Mar 13 https://www1.racgp.org.au/newsgp/professional/chief-medical-officer-update-oncoronavirus-testin.

12 O'Rourke G. Revealed: The rebates and rules for claiming the new GP telehealth items. Ausdoc 2020 Mar 13. https://www.ausdoc.com.au/news/revealed-rebates-and-rulesclaiming-new-gp-telehealth-items.

13 Papworth T. Coronavirus: Melbourne doctor treats patients in car park. Age 2020 Mar 8. https://www.theage.com.au/national/victoria/doctor-takes-to-the-carpark-to-treatcoronavirus-20200308-p5482n.html.

14 Wuhan closes last makeshift coronavirus hospital as China's infection rate falls-video Guardian 2020. https://www.theguardian.com/world/video/2020/mar/10/wuhan-closeslast-makeshift-coronavirus-hospital-video.

15 Barigazzi J. Italy's foreign minister hails Chinese coronavirus aid. Politico 2020 Mar 13. https://www.politico.eu/article/italys-foreign-minister-hails-chinese-caronavirus-aid/.

16 Wen X. Beijing's Xiaotangshan Hospital to open soon. China Daily 2020 Feb 18.

17 Macron announces a two-week lockdown in France, closure of EU's Schengen zone borders. France 242020 Mar 16. https://www.france24.com/en/20200316-france-scoronavirus-situation-deteriorating-very-fast-health-chief-says.

18 Coronavirus is France's "greatest health crisis in a century" says Macron. France 24 2020 Mar 12. https://www.france24.com/en/20200312-coronavirus-is-france-s-greatesthealth-crisis-in-a-century-says-macron.

19 More than half of coronavirus cases in France under intensive care are below the age of 60. CNN 2020 Mar 16. https://edition.cnn.com/world/live-news/coronavirus-outbreak-0316-20-intl-hnk/h_91b13ce4323d365087bad47c5c9a8c39.

20 Picheta R. France says ibuprofen may aggravate coronavirus. Experts say more evidence is needed. CNN 2020 Mar 17. https://edition.cnn.com/2020/03/16/health/coronavirusibuprofen-french-health-minister-scn-intl-scli/index.html.

21 Day M. Covid-19: ibuprofen should not be used for managing symptoms, say doctors and scientists. BMJ 2020;368:m108610.1136/bmj.m1086.

22 Coronavirus: Germany latest country to close borders. BBC 2020 Mar 16. https://www. bbc.co.uk/news/world-europe-51905129.

23 Coronavirus: anger in Germany at report Trump seeking exclusive vaccine deal. Guardian 2020 Mar 16. https://www.theguardian.com/world/2020/mar/16/not-for-sale-anger-ingermany-at-report-trump-seeking-exclusive-coronavirus-vaccine-deal.

24 Iran says worsening outbreak could strain health facilities. Politico 2020 Mar 15. https:// www.politico.com/news/2020/03/15/iran-says-worsening-outbreak-could-strain-healthfacilities-129895

25 Johns Hopkins University. Coronavirus COVID-19 global cases by the Center for Systems Science and Engineering. 2020. https://coronavirus.jhu.edu/map.html.

26 Bote J. At least 44 dead from drinking toxic alcohol in Iran after coronavirus cure rumor. USA Today 2020 Mar 11. https://eu.usatoday.com/story/news/world/2020/03/10/44-dead iran-drinking-toxic-alcohol-fake-coronavirus-cure/5009761002/.

27 Slobodian SR. Evening Update: Canada closing borders to most non-citizens amid coronavirus outbreak; world markets slide again. Globe and Mail 2020 Mar 16. https:// www.theglobeandmail.com/canada/article-evening-update-canada-closing-borders-tomost-non-citizens-amid/.

28 Canada's Chief Medical Officer Dr. Theresa Tam says government needs to "act now" to contain coronavirus epidemic. Globe and Mail 2020 Mar 15. https://www.theglobeandmail. com/canada/article-canadas-chief-medical-officer-dr-theresa-tam-says-government-needs/

29 Countries urge citizens to return home and long trials put on hold in UK over Covid-19-as it happened. Guardian 2020 Mar 18. https://www.theguardian.com/world/live/2020/mar/ 17/coronavirus-live-news-updates-uk-us-australia-europe-france-italy-who-self-isolationtravel-bans-borders-latest-update.

30 Paterlini M. On the front lines of coronavirus: the Italian response to covid-19. BMJ 2020;368:m1065. 10.1136/bmj.m1065 32179517

Published by the BMJ Publishing Group Limited. For permission to use (where not already granted under a licence) please go to http://group.bmj.com/group/rights-licensing/ permissions 


\section{Figure}

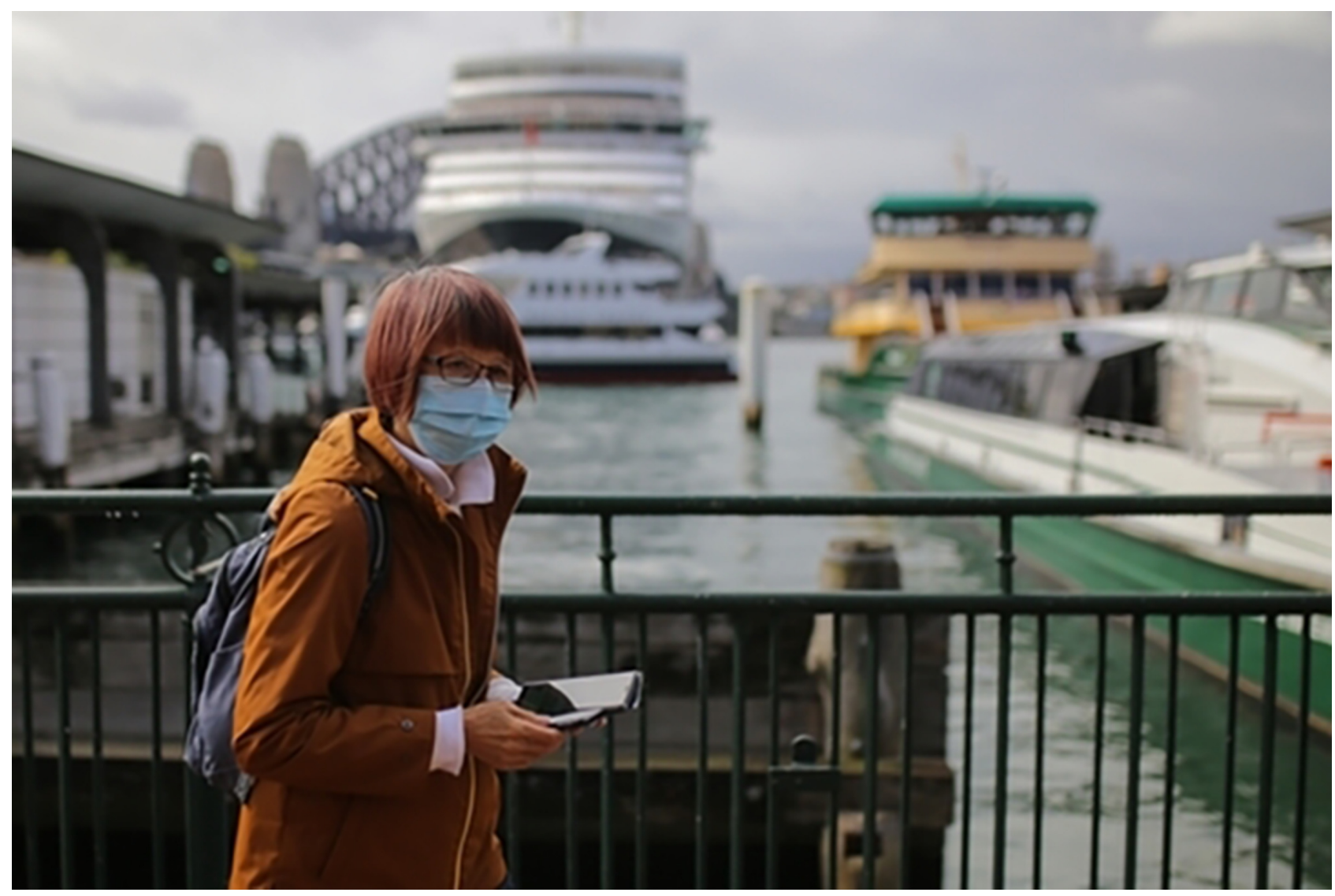

[Image: Credit: Saphore S] 